\title{
Translation and adaptation of functional auditory performance indicators (FAPI)
}

Karina FERREIRA ${ }^{1}$, Adriane Lima Mortari MORET ${ }^{2}$, Maria Cecilia BEVILACQUA ${ }^{3}$, Regina de Souza Tangerino JACOB ${ }^{2}$ 1- MSc Graduate student (Master degree), Department of Speech-Language Pathology and Audiology. Bauru School of Dentistry, University of São Paulo,
Bauru, SP, Brazil.
2-MSc, PhD, Assistant Professor, Department of Speech-Language Pathology and Audiology, Bauru School of Dentistry, University of São Paulo, Bauru, SP, Brazil.
3- MSc, PhD, Full Professor, Department of Speech-Language Pathology and Audiology, Bauru School of Dentistry, University of São Paulo, Bauru, SP, Brazil.
Corresponding address: Karina Ferreira - Rua Capitão Gomes Duarte, $20-40$ - apto 508 - Vila Universitária - Bauru-SP - Brasil - $17012-226$ - Phone: 55
(14) $8811-4631$ / 55 (14) 3206-4631 - e-mail: kafe_carie@yahoo.com.br

Received: July 24, 2010 - Accepted: September 15, 2011

\section{ABSTRACT}

W ork with deaf children has gained new attention since the expectation and goal of therapy has expanded to language development and subsequent language learning. Many clinical tests were developed for evaluation of speech sound perception in young children in response to the need for accurate assessment of hearing skills that developed from the use of individual hearing aids or cochlear implants. These tests also allow the evaluation of the rehabilitation program. However, few of these tests are available in Portuguese. Evaluation with the Functional Auditory Performance Indicators (FAPI) generates a child's functional auditory skills profile, which lists auditory skills in an integrated and hierarchical order. It has seven hierarchical categories, including sound awareness, meaningful sound, auditory feedback, sound source localizing, auditory discrimination, short-term auditory memory, and linguistic auditory processing. FAPI evaluation allows the therapist to map the child's hearing profile performance, determine the target for increasing the hearing abilities, and develop an effective therapeutic plan. Objective: Since the FAPI is an American test, the inventory was adapted for application in the Brazilian population. Material and Methods: The translation was done following the steps of translation and back translation, and reproducibility was evaluated. Four translated versions (two originals and two back-translated) were compared, and revisions were done to ensure language adaptation and grammatical and idiomatic equivalence. Results: The inventory was duly translated and adapted. Conclusion: Further studies about the application of the translated FAPI are necessary to make the test practicable in Brazilian clinical use.

Key words: Child. Hearing loss. Speech perception. Auditory perception. Hearing impaired rehabilitation. Therapy.

\section{INTRODUCTION}

In early childhood, children depend primarily on their senses as a means of apprehending the exterior world, to gain experiences that will promote their psycho-social development ${ }^{5}$. The anatomical and physiological integrity of the auditory system and hearing sensitivity are crucial for oral language normal acquisition and development ${ }^{18}$. Therefore, language, learning, cognitive development and social inclusion of children may be affected by any type of hearing $\operatorname{loss}^{27}$.

Hearing loss $(\mathrm{HL})$ impairs overall development of children and, in particular, their language, due to the difficulty of receiving the acoustic stimulus through the auditory system ${ }^{26}$. The critical periods for language development are limited to brain maturation periods, stages that must coincide with exposure to certain sensory experiences, resulting in fast acquisition of new skills, which are impossible or very difficult to be acquired during other phases ${ }^{15}$. Thus, the importance of hearing for oral language development becomes evident and any type or degree of $\mathrm{HL}$ interferes with oral communication as a whole.

Recent scientific and technological advances have made possible the early detection and intervention of $\mathrm{HL}$, minimizing its consequences ${ }^{24}$. Early identification 
of hearing impairment allows interventions in the critical and also ideal period for speech and hearing stimulation, since the maturation of the central auditory system occurs during the first years of life. Auditory experience during this period of greater brain plasticity, where new neural connections are established, is essential to ensure the development of hearing and language ${ }^{28}$.

The scientific and technological advances of the last ten years have enabled the identification of newborn $\mathrm{HL}$, resulting in the increasing deployment of newborn hearing screening programs. According to the Brazilian Committee of Hearing Loss in Childhood, its deployment is recommended for all children at birth or no later than three months old ${ }^{9}$. In confirmed cases of $\mathrm{HL}$, a unique opportunity is created for researchers and professionals to study the (re)habilitation of $\mathrm{HL}$ through the therapeutic process, the proper stimulation for central auditory pathway maturation as well as development of the hearing function and oral language ${ }^{16}$.

It is known that there is a gradual acquisition sequence of listening skills ${ }^{4}$. In this context, the quality of social interactions has an important role in children's language building ${ }^{23}$. Several clinical trials have been developed to evaluate the perception of speech sounds in young children to determine exactly what listening skills are developed from the use of individual hearing aids ( $\mathrm{HA}$ ) or the cochlear implant $(\mathrm{CI})^{10}$. However, few of these tests are available in Portuguese. In Brazil, the lack of formal instruments and commercially available tools designed for evaluation and diagnosis in the speech therapy field is significant. We know that the real objectives of an evaluation process can only be achieved when adequate tools and procedures are used ${ }^{13}$.

One way that some researchers have found to alleviate this problem is to translate instruments that are already available in other languages rather than creating new ones. In addition to alleviating this shortage, the procedure may contribute to another aspect that also has great scientific relevance, that of cross-cultural studies, which can bring knowledge and understanding of the management of communication disorders and their specificities in different languages ${ }^{13}$.

In the Audiology area, some instruments, translated and adapted to the Portuguese language, have been used in clinical protocols of public hearing health services, referenced by the Health Ministry. Among these instruments are the Deep Hearing Impaired Children Evaluation Procedure ${ }^{6}$, adapted from the Glendonald Auditory Screening Procedure (GASP, Words and Sentences) ${ }^{11}$; the Meaningful Use of Speech Scales: MUSS ${ }^{21}$; the Infant Toddler: Meaningful Auditory Integration Scale (ITMAIS $)^{29}$; the Minimum Hearing Capacity Evaluation Test $(\text { TACAM })^{19}$, adapted from the Early Speech
Perception Test: ESP17; and the Meaningful Auditory Integration Scale (MAIS) ${ }^{22}$, adapted for Castiquini and Bevilacqua ${ }^{8}$ (2000), among others.

The Working Group of the American SpeechLanguage-Hearing Association (ASHA) ${ }^{1}$ developed guidelines that were approved by the Legislative Council (LC) in November 2004 as part of meeting the need for more specific protocols and procedures to assist children from birth up to five years with $\mathrm{HL}$ in all settings. These guidelines established that for audiological assessment of auditory skills in hearing impaired children of the specified age, some tools should be used, such as the Early Listening Function $(E L F)^{2}$ and the Functional Auditory Performance Indicators (FAPI) inventory ${ }^{25}$. For the children in this age with severe to profound $\mathrm{HL}$, the Infant-Toddler Meaningful Auditory Integration Scale (IT-MAIS) ${ }^{29}$ was identified as a suitable tool. However, only the ITMAIS and ELF have been translated into Portuguese ${ }^{19}$. Those available tools cannot evaluate all hearing skills. The IT-MAIS ${ }^{29}$ was used in very young children to evaluate auditory feedback (speech changes with hearing aids) attention for environmental sounds and their meaning, and ELF² was used to evaluate sound detection.

The evaluation using the FAPI ${ }^{25}$ generates a functional profile of a child's auditory skills after administering all items on the list, which has seven hierarchical categories. The auditory performance indicators are also listed in hierarchical order in each category. Although this scale is hierarchical, it is also suitable for the child to work on several skills at once, as four to eight skills can be addressed simultaneously. While working in several different categories of skills, children can learn how to integrate and develop their listening skills. The child's hearing profile performance goals can be given to increase listening skills and develop a treatment planning.

The motivation for this work was contributing to the improvement of protocols for auditory skills evaluation in hearing impaired children.

\section{OBJECTIVES}

The objective of this work was to translate and adapt the FAPI to the Portuguese language.

\section{MATERIAL AND METHODS}

The translation and cultural adaptation of the FAPI inventory followed several steps ${ }^{14}$. The first step was the translation (forward) of the original instrument from English to Portuguese. This is a very complex activity because, when translating an instrument, several types of equivalence to the original are searched, such as cultural, semantic, technological, the content, the criterion, and conceptual. A 
useful technique in this regard was the back translation, whereby translation of the instrument was re-translated (back translated) into the original language. The translation and back translation were done by a bilingual translator with experience in both cultures. Both versions (the original and back translated) were then compared. It is important to mention that such comparison maintained the equivalence at the different levels mentioned above.

Therefore, besides the translation, a linguistic adaptation, a grammatical and idiomatic equivalence revision, and an evaluation using the Brazilian FAPI were performed.

\section{Translation}

The FAPI is composed of auditory skills lists, integrated in a hierarchical order, covering seven categories: awareness of sound, meaningful sound, auditory feedback, location of the sound source, auditory discrimination, short-term auditory memory and auditory processing, and was distributed to two fluent English translators/interpreters who did not know each other and did not previously know the questionnaire. The translators individually and secretly prepared the first version in Portuguese. This procedure was performed with the aim of generating two independent translations of the FAPI.

The reviser group was composed of two audiologists (Brazilian, with English fluency), who analyzed both documents and, by consensus, reduced the differences they found in the translations, choosing the best expressions and words in all questions, adapting the text to Brazilian culture.

This step consisted of choosing the best translation for the questions and the change in more appropriate terms, chosen to accommodate the understanding of the Brazilian population. Thus, a new and unique inventory was obtained, called the Functional Auditory Performance Indicators Brasileiro (Brazilian FAPI).

\section{Review of grammatical and idiomatic equivalence}

A copy of the Brazilian FAPI was sent to two different translators with the same linguistic and cultural conditions of the first ones. These translators, who did not know about the original text, realized a new version for the English language.

These new translators were not allowed to read the original text, written in English, thus avoiding any influence on the translation of words. The same reviser group did a new evaluation of the two resulting versions and then compared it with the original English version.

\section{First evaluation using the Brazilian FAPI}

The Brazilian FAPI was applied in a profound hearing impaired child aged seven years and four months, a cochlear implant user since she was four.

The study was approved by Ethics Committee
(CEP, FOB-USP), under the protocol 62/2008, and the child's parents signed an Informed Consent Form agreeing to participate in research and to allow the publication of results.

\section{RESULTS}

The results are shown on Figures 1 and 2 .

\section{DISCUSSION}

It was difficult to find translators who had English language proficiency and knowledge of technical terms used in the performed task area. According to Guillemin, et al. ${ }^{14}$ (1993), cultural equivalence is established and the study population has no difficulties in understanding the questions or the terms used when at least $80 \%$ of individuals do not show difficulty in answering each asked question. If this number exceeds the limit of $80 \%$, this question should be individually submitted to a new translation and release process. However, it was not possible to establish this parameter due to the application of it in just one child, but the degree to which she understood the questions was easily verified by the child, her parents, and the researcher.

It was found that the FAPI should be applied at different times due to its length, since the child became distracted in a single session and it was necessary to complete the application in a second session. Activities in which the responses were not consistent with information from the parents were used as a criterion for the final scoring of the listening skills displayed by the child.

In the original FAPI text, there are some missing directions about the form and type of sound stimulus application. The application mode in noise is not standardized or described in terms of type, intensity, and distance - for example, ambient sound or intentionally caused sounds, such as songs. During the evaluations, speech comprehension is affected by many factors, such as material presentation level, presentation type, and listener response characteristics, including language experiences and auditory system conditions ${ }^{12}$. Thus, emphasis is given to the importance of noise testing, since patients with the same abilities of speech recognition in quiet environments may have vastly different results in noisy environments.

In the sound source location category, the distance measurement is not well established, as the sound source positioning being "inside", "off", or "other room". In the auditory discrimination category, speech materials for items held in an open or closed set were taken from the GASP tests ${ }^{6}$ and TIPITI 7 , both already published in Portuguese, to identify Portuguese words based on different vowels, consonants, and syllables.

In the linguistic hearing processing category, 
some words/examples were replaced by similar ones because the original terms did not correspond to the normally conducted activities of the Brazilian population. It is necessary that the evaluation include tests of real communication and not only tests to investigate the perception of single words, because otherwise the language and the child's hearing may be limited to a single rated aspect ${ }^{20}$.

The foreign instrument's translation and adaptation should adopt judicious and careful procedures since the translation and adaptation are as important as the construction of a new instrument. It is necessary to repeat validity and reliability studies in the new context ${ }^{13}$.

Thus, we suggest further investigations with the Brazilian FAPI in order to verify the reliability and reproducibility of the same scenario in the National Educational Audiology Clinic, because the adaptation for use in Brazil of a standardized instrument allows comparison with the results of international studies. The lack of formal instruments and objectives, while certainly reflected in the diagnosis, also is reflected in the medical management definition and in the contingency plan preparation, compromising the efficiency and effectiveness of the offered treatments ${ }^{3}$.

\section{CONCLUSION}

The FAPI was translated into the Portuguese language, resulting in the Brazilian FAPI, but further studies are needed to evaluate its reliability.

It is noteworthy that the FAPI has the potential to contribute to the identification of targets in therapeutic treatment plans for deaf children, since it generates the functional profile of children's listening skills.

\section{REFERENCES}

1- American Speech-Language-Hearing Association. Guidelines for the audiologic assessment of children from birth to 5 years of age [online]. 2004. [cited 2010 July $14^{\text {th }}$ ]. Available from: <http://www. asha.org/docs/html/gl2004-00002.html>.

2- Anderson KL. Early Listening Function: discovery tool for parents and caregivers of infants and toddlers [online]. 2002. [cited 2010 July $14^{\text {th }}$. Available from: <http://www.hear2learn.com/Inventories/ ELF_Questionnaire.pdf $>$.

3- Andrade CRF, Juste F. Proposta de análise de performance e de evolução em crianças com gagueira desenvolvimental. Revista Cefac. 2005;7(2):158-70.

4- Bevilacqua MC, Formigoni GMP. O desenvolvimento das habilidades auditivas. In: Bevilacqua MC, Moret ALM. Deficiência auditiva: conversando com familiares e profissionais de saúde. São José dos Campos: Pulso, 2005. p. 179-201.

5- Bevilacqua MC, Moret ALM. Conversando com familiares e profissionais de saúde. São José dos Campos: Pulso; 2005.

6- Bevilacqua MC, Tech EA. Elaboração de um procedimento de avaliação de percepção de fala em crianças deficientes auditivas profundas a partir de cinco anos de idade. In: Marchesan IQ, Zorzi JL, Gomes ICD, editors. Tópicos em Fonoaudiologia. São Paulo: Lovise; 1996. p. 411-33.
7- Braz HA, Pellicciotti THF. Exame de linguagem TIPITI. São Paulo: MJN; 1988.

8- Castiquini EAT, Bevilacqua MC. Escala de integração auditiva significativa: procedimento adaptado para a avaliação da percepção da fala. Rev Soc Bras Fonoaudiol. 2000;6:51-60.

9- Comitê Brasileiro sobre Perdas Auditivas na Infância - CBPAI. Recomendação 01/99 do Comitê Brasileiro sobre perdas auditivas na infância. J Cons Fed Fonoaudiol. 2000;5:3-7.

10- Delgado-Pinheiro EMC, Castiquini EAT, Lopes AC, Bevilacqua MC. Parâmetros consuderados nos procedimentos de avaliação da percepção dos sons da fala. Pró-Fono. 2003;15(3):317-24.

11- Erber NP. Auditory training. Washington, DC: AG Bell Publications; 1982.

12- Freitas CD, Lopes LFD, Costa MJ. Confiabilidade dos limiares de reconhecimento de sentenças no silêncio e no ruído. Rev Bras Otorrinolaringol. 2005;71(5):624-30.

13- Giusti E, Befi-Lopes DM. Translation and cross-cultural adaptation of instruments to the Brazilian Portuguese language. Pró-Fono. 2008;20(3):207-10.

14- Guillemin F, Bombardier C, Beaton D. Cross-cultural adaptation of health-related quality of life measures: literature review and proposed guidelines. J Clin Epidemiol. 1993;46(12):1417-32.

15- Klein K, Rapin I. Perda intermitente da audição de condução e desenvolvimento da linguagem. In: Bishop D, Morgford K. Desenvolvimento da linguagem em circunstâncias excepcionais. Rio de Janeiro: Revinter; 2002. p.123-43.

16- Martinez MANS. Avaliação audiológica na criança. In: Ferreira LP, Befi-Lopes, DM, Limongi SCO. Tratado de Fonoaudiologia. São Paulo: Roca; 2004. p. 597-603.

17- Moog JS, Geers AE. Early speech perception test for profoundly hearing-impaired children. St. Louis: Central Institute for the Deaf; 1990.

18- Most T, Shina-August E, Meilijson S. Pragmatic abilities of children with hearing loss using cochlear implants or hearing aids compared to hearing children. J Deaf Stud Deaf Educ. 2010;15(4):422-37.

19- Orlandi $A C L$, Bevilacqua MC. Profoundly deaf in the first years old of life: procedure for speech perception evaluation. Pró-Fono. 1999;10(2):87-91.

20- Robbins AM, Green J, Bollard P. Language development in children following one year of Clarion implant use. Ann Otol Rhinol Laryngol Suppl. 2000;185:94-5.

21- Robbins AM, Osberger MJ. Meaningful Use of Speech Scale (MUSS). Indianopolis: Indiana University School of Medicine; 1990.

22- Robbins AM, Renshaw JJ, Berry SW. Evaluating meaningful auditory integration in profoundly hearing-impaired children. Am J Otol. 1991;12:144-50.

23- Santana AP. O processo de construção da linguagem: estudo comparativo de duas crianças usuárias de implante coclear. Rev Dist Comun. 2005;17(2):233-43.

24- Schramm B, Bohnert A, Keilmann A. Auditory, speech and language development in young children with cochlear implants compared with children with normal hearing. Int J Pediatr Otorhinolaryngol. 2010;74(7):812-9.

25- Stredler-Brown A., Johnson CD. Functional auditory performance indicators: An integrated approach to auditory skills development. [online]. Colorado Department of Education, Special Education Services Unit, 2001-2004. [cited 2010 July 14th . Available from: <http://www. cde.state.co.us/cdesped/download/pdf/FAPI_3-1-04g.pdf >.

26- Stuchi RF, Nascimento LT, Bevilacqua MC, Brito Neto RV. Oral language in children with five years of experience using cochlear implant. Pró-Fono. 2007;19(2):167-76.

27- Vieira ABC, Macedo LR, Gonçalves DU. The diagnosis of hearing loss in childhood. Pediatria (São Paulo). 2007;29(1):43-9.

28- Zakirullah MN, Mukhtar N, Khan MI, Shah SA. Evaluation of auditory perception skills development in profoundly deaf children following cochlear implantation. J Ayub Med Coll Abbottabad. 2008;20(1):94-7.

29- Zimmerman-Phillips S, Osberger MJ, Robbins AM. Infant-Toddler: Meaningful Auditory Integration Scale (IT-MAIS). Sylmar: Advanced Bionics Corporation; 1997. 
Nome:

Tipo de amplificação:

Uso: ( ) Coerente

() Nāo coerente

Examinador:

$\mathrm{N}=$ não presente $(0-10 \%) \quad \mathrm{E}=$ emergente $(11-35 \%) \quad \mathrm{P}=$ em processo $(36-79 \%) \quad \mathrm{A}=$ adquirido $(80-100 \%)$

\begin{tabular}{|c|c|c|c|}
\hline $\begin{array}{l}\text { Categoria de } \\
\text { Desenvolvimento } \\
\text { Auditivo }\end{array}$ & Indicadores de Desempenho Auditivo & $\begin{array}{c}\text { Pontuação } \\
\begin{array}{c}N=0-10 \%, \quad E=11-35 \% \\
P=36-79 \%, \quad A=80-100 \%\end{array}\end{array}$ & $\begin{array}{c}\text { Observaçōes } \\
\text { e } \\
\text { Comentários }\end{array}$ \\
\hline & 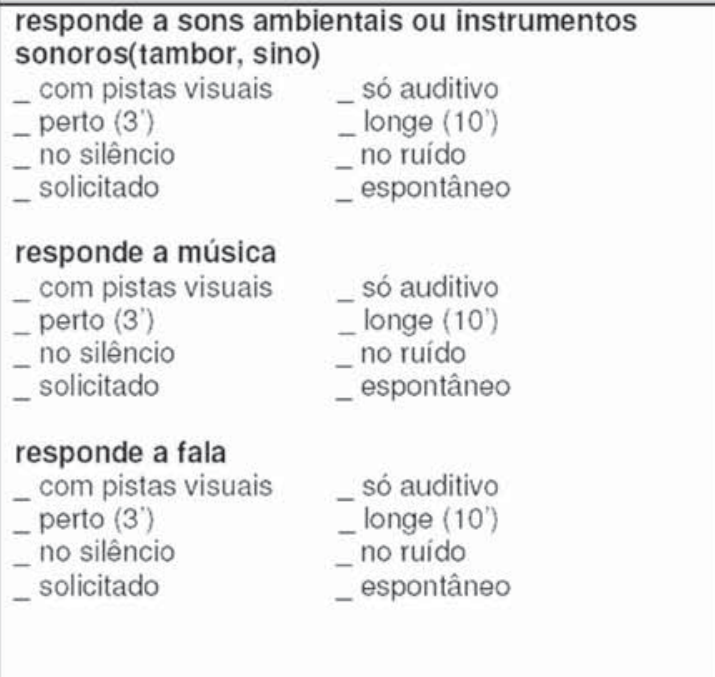 & 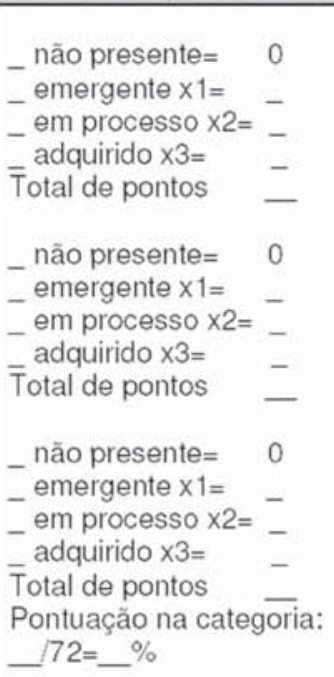 & \\
\hline & 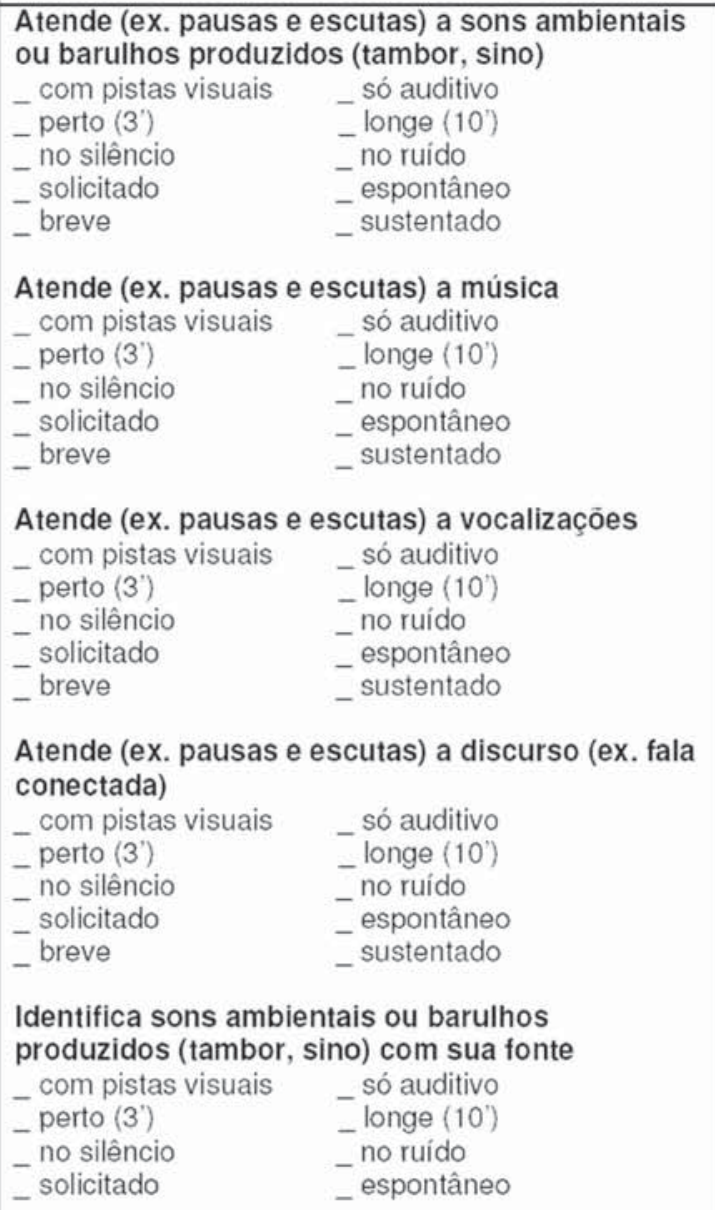 & 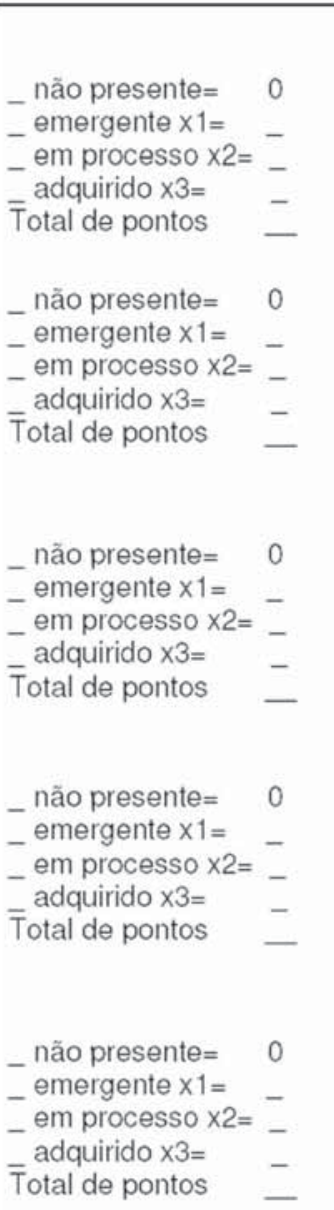 & \\
\hline
\end{tabular}

Figures 1A- Final FAPI translation into Portuguese (original in English: Stredler-Brown \& Johnson ${ }^{25}$ ) 


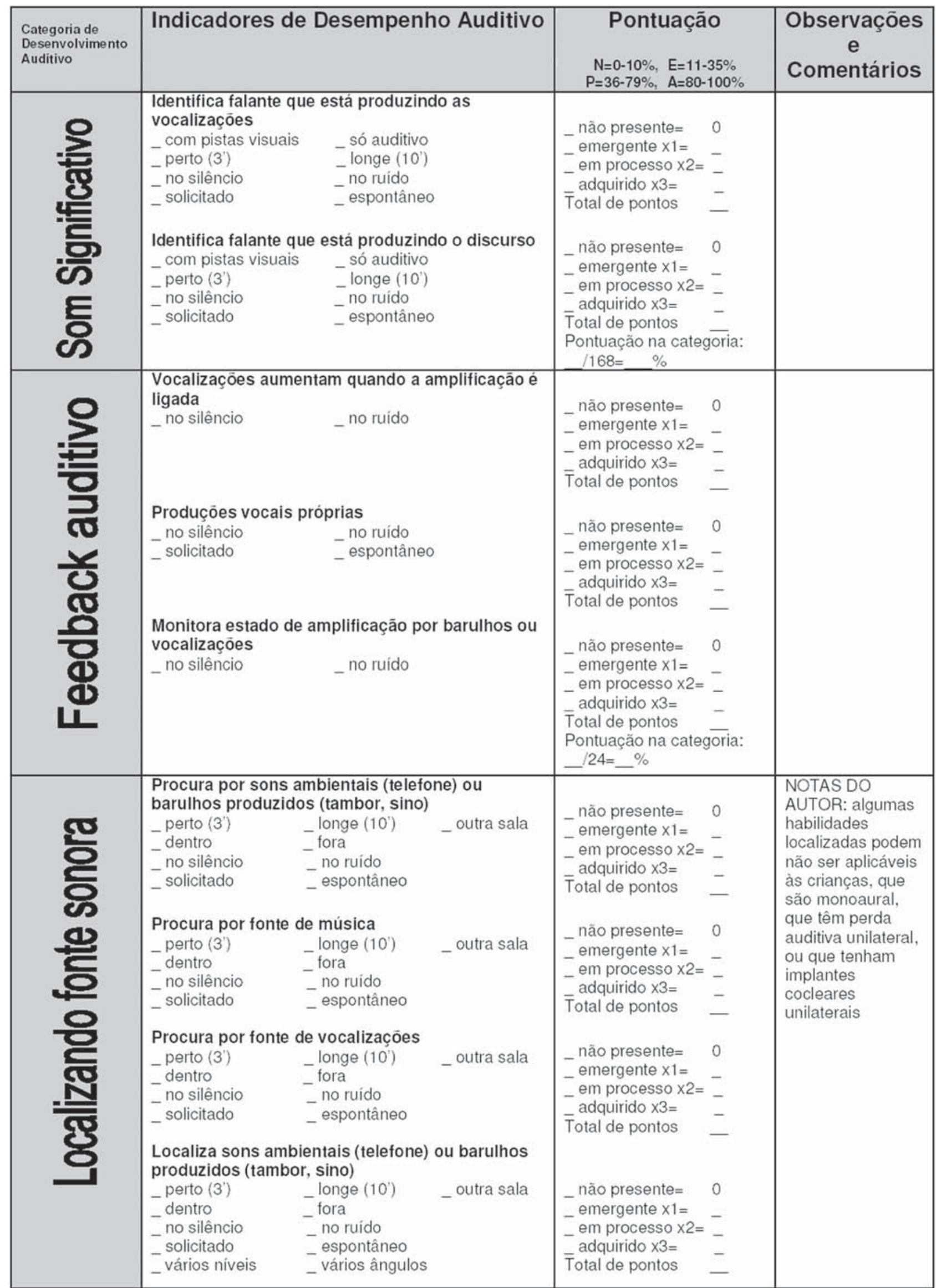

Figures 1B- Final FAPI translation into Portuguese (original in English: Stredler-Brown \& Johnson ${ }^{25}$ ) 


\begin{tabular}{|c|c|c|c|}
\hline $\begin{array}{l}\text { Categoria de } \\
\text { Desenvolvimento } \\
\text { Auditivo }\end{array}$ & Indicadores de Desempenho Auditivo & $\begin{array}{c}\text { Pontuação } \\
N=0-10 \%, \quad E=11-35 \% \\
P=36-79 \%, \quad A=80-100 \%\end{array}$ & $\begin{array}{l}\text { Observaçōes e } \\
\text { Comentários }\end{array}$ \\
\hline$\frac{5}{20}$ & 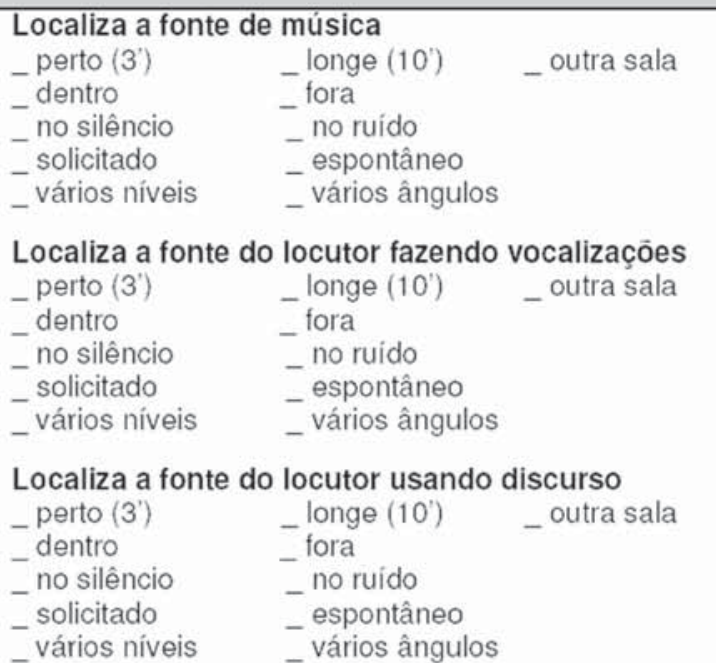 & 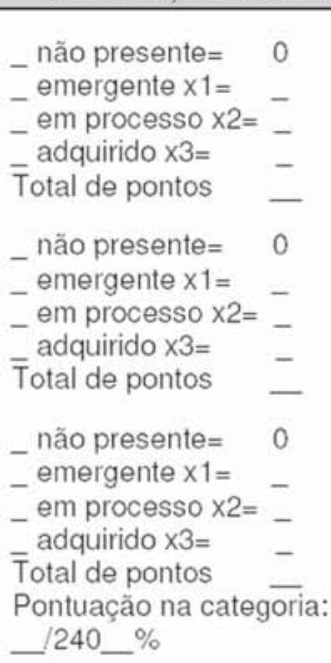 & \\
\hline & 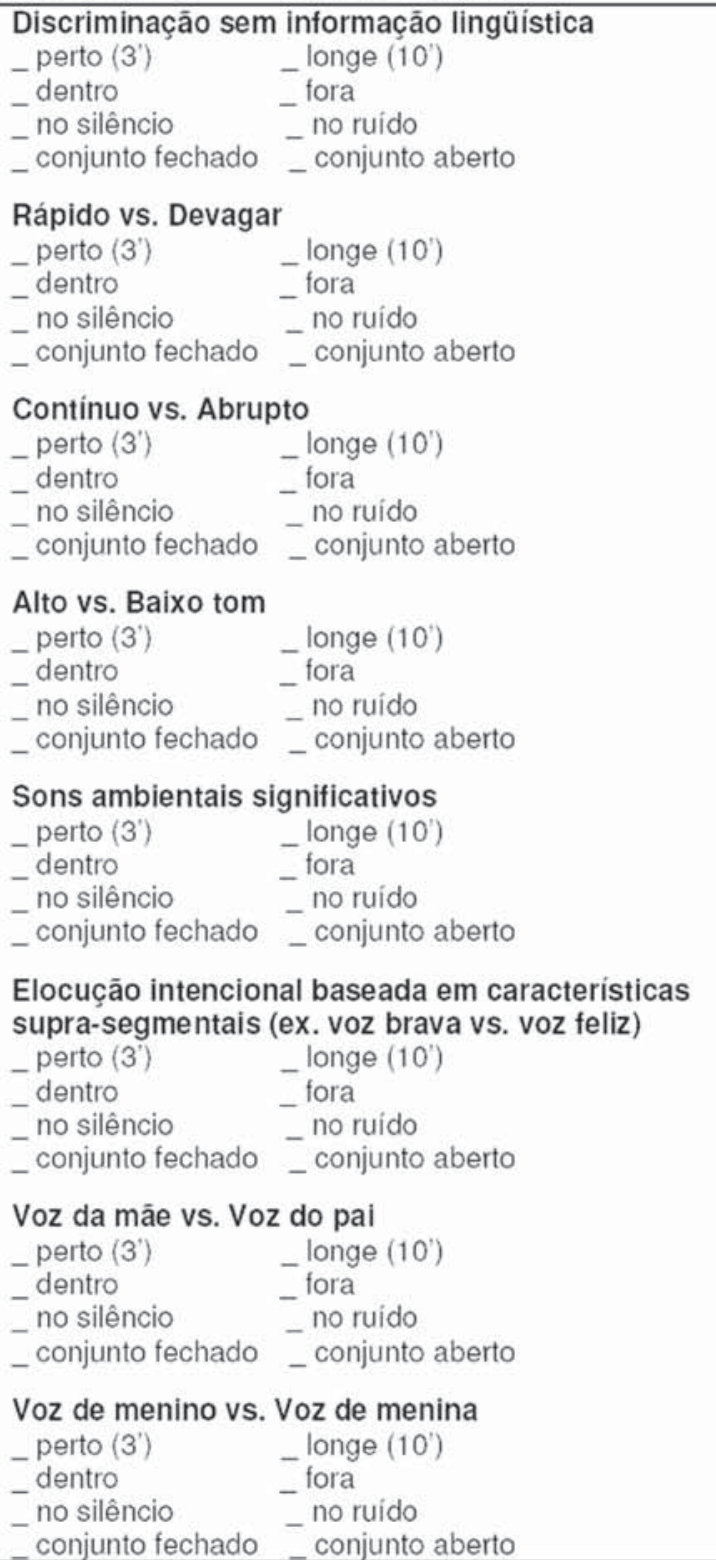 & 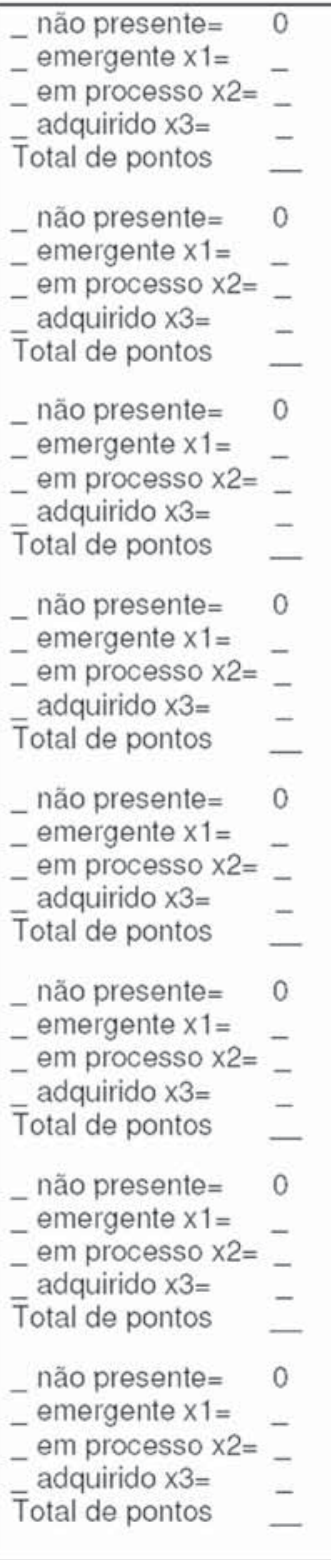 & \\
\hline
\end{tabular}

Figures 1C- Final FAPI translation into Portuguese (original in English:Stredler-Brown \& Johnson ${ }^{25}$ ) 


\begin{tabular}{|c|c|c|c|}
\hline $\begin{array}{l}\text { Categoria de } \\
\text { Desenvolvimento } \\
\text { Auditivo }\end{array}$ & Indicadores de Desempenho Auditivo & $\begin{array}{c}\text { Pontuaçāo } \\
N=0-10 \%, \quad E=11-35 \% \\
P=36-79 \%, \quad A=80-100 \%\end{array}$ & $\begin{array}{c}\text { Observaçōes e } \\
\text { Comentários }\end{array}$ \\
\hline & 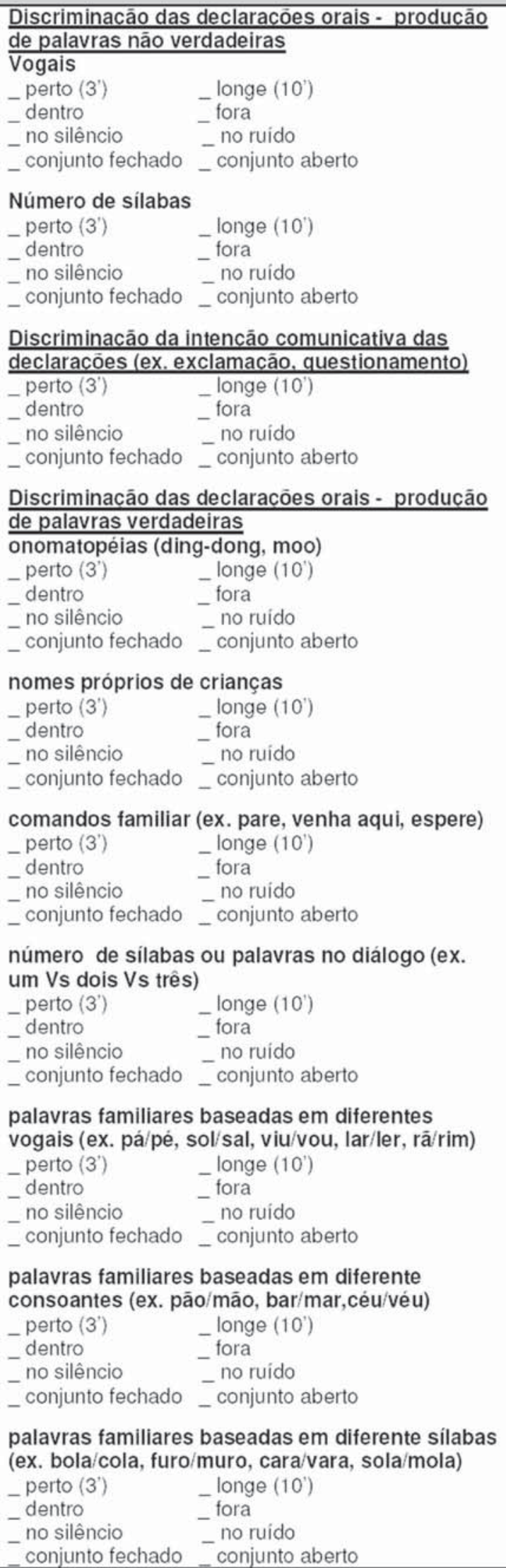 & 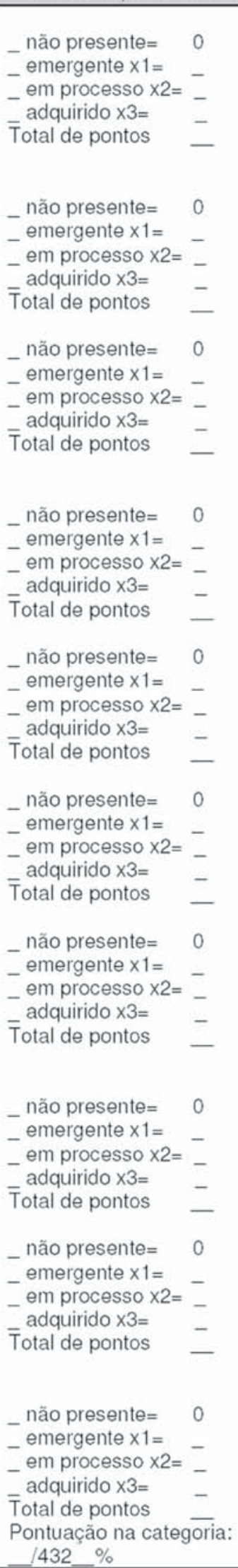 & \\
\hline
\end{tabular}

Figures 1D- Final FAPI translation into Portuguese (original in English: Stredler-Brown \& Johnson ${ }^{25} 2004$ ) 


\begin{tabular}{|c|c|c|c|}
\hline $\begin{array}{l}\text { Categoria de } \\
\text { Desenvolvimento } \\
\text { Auditivo }\end{array}$ & Indicadores de Desempenho Auditivo & $\begin{array}{c}\text { Pontuação } \\
\begin{array}{c}N=0-10 \%, \quad E=11-35 \% \\
P=36-79 \%, \quad A=80-100 \%\end{array}\end{array}$ & $\begin{array}{c}\text { Observações e } \\
\text { Comentários }\end{array}$ \\
\hline 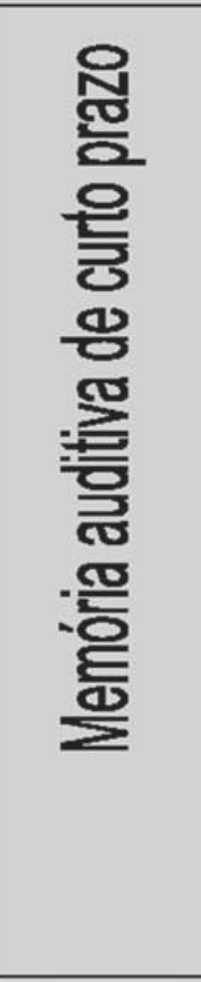 & 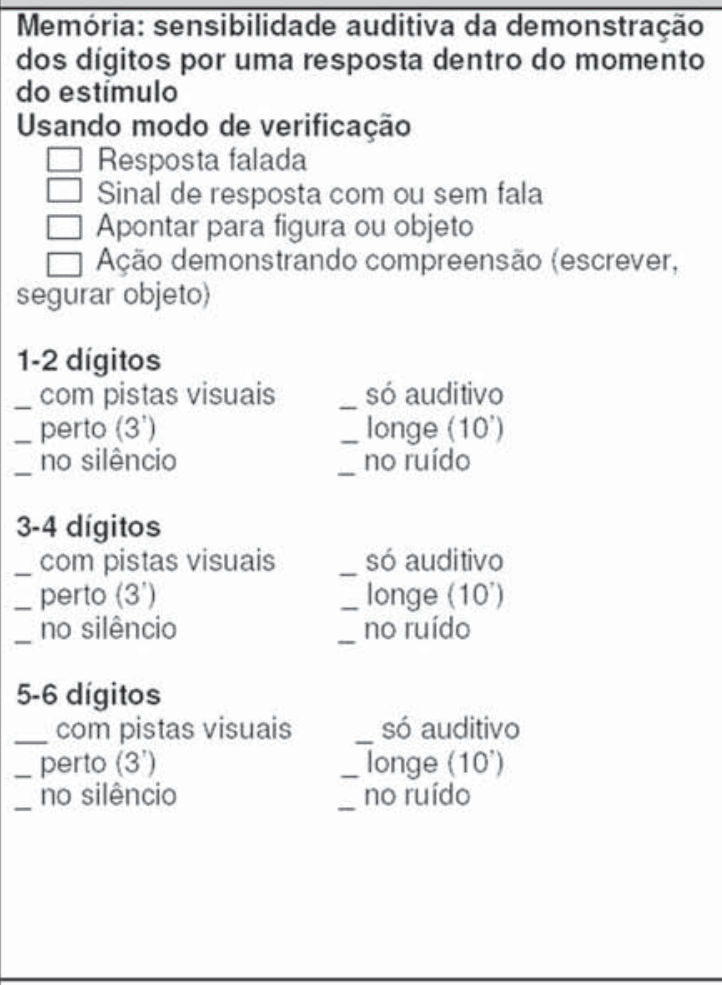 & 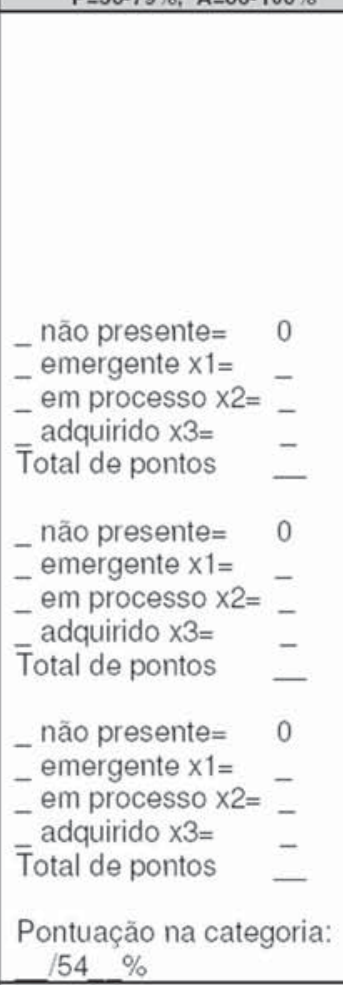 & \\
\hline 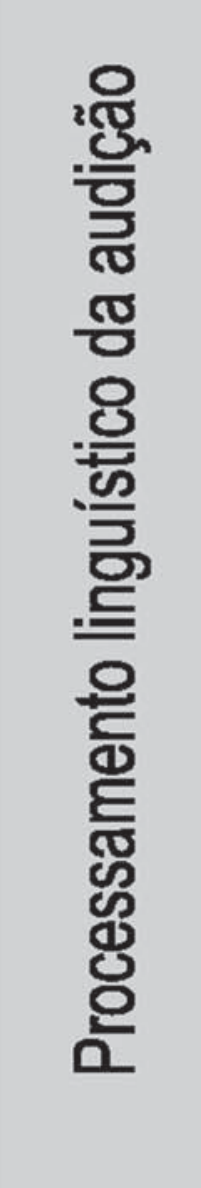 & 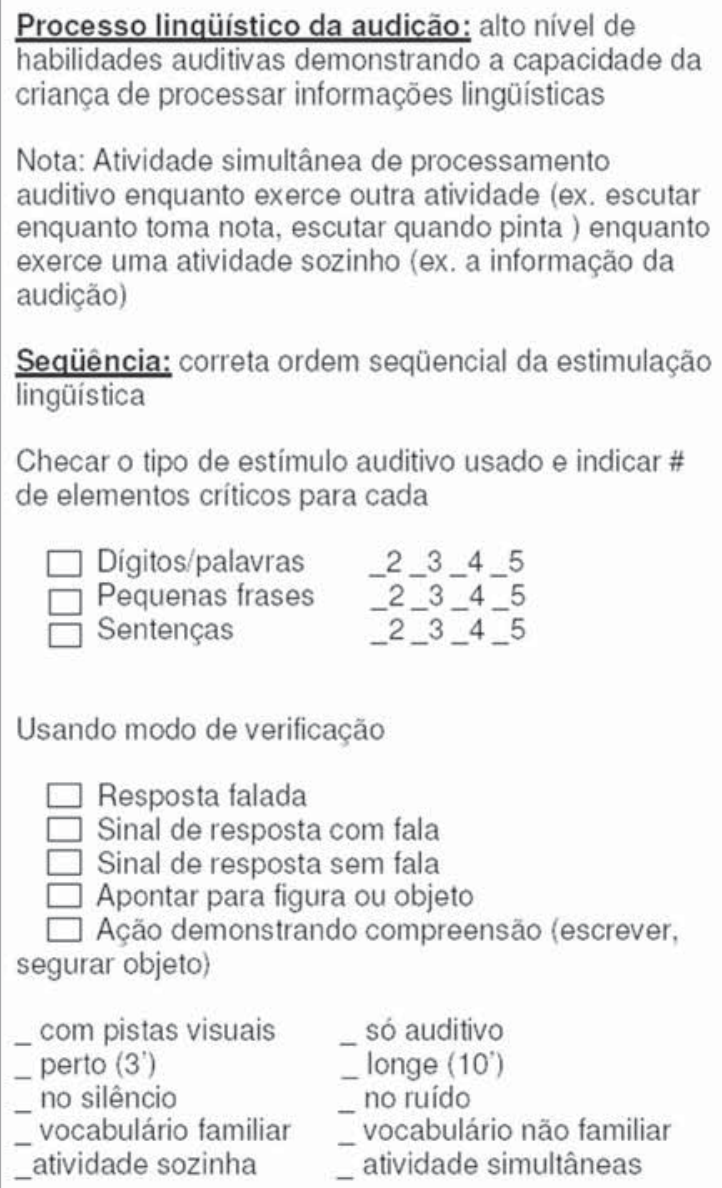 & $\begin{array}{ll}\text { não presente }= & 0 \\
- \text { emergente } \times 1= & - \\
\text { em processo } \times 2= & \text { - } \\
\text { em adquirido } \times 3= & \text { - } \\
\text { Total de pontos } & -\end{array}$ & \\
\hline
\end{tabular}

Figures 1E- Final FAPI translation into Portuguese (original in English: Stredler-Brown \& Johnson ${ }^{25}$ ) 


\begin{tabular}{|c|c|c|c|}
\hline $\begin{array}{l}\text { Categoria de } \\
\text { Desenviolvimento } \\
\text { Auditivo }\end{array}$ & Indicadores de Desempenho Auditivo & $\begin{array}{c}\text { Pontuação } \\
\begin{array}{c}N=0-10 \%, E=11-35 \% \\
P=36-79 \%, A=80-100 \%\end{array}\end{array}$ & $\begin{array}{c}\text { Observações e } \\
\text { Comentários }\end{array}$ \\
\hline 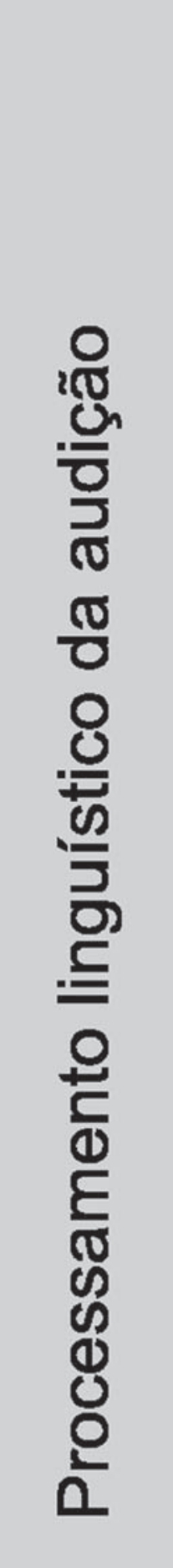 & 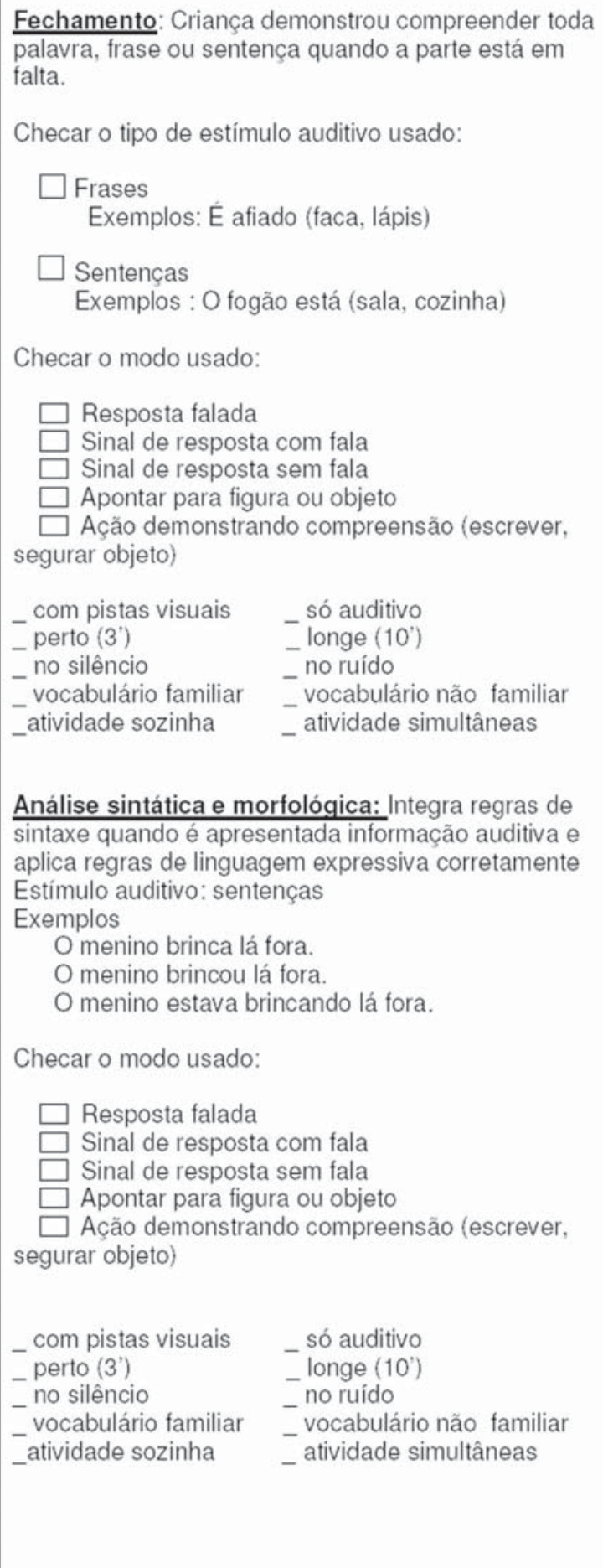 & $\begin{array}{ll}\text { não presente= } & 0 \\
\text { emergente } \times 1= & - \\
\text { em processo } \times 2= & - \\
\text { em } & \\
\text { adquirido } \times 3= & - \\
\text { Total de pontos } & - \\
& \\
& \\
& \\
& \\
& \\
& \\
\text { - não presente }= & 0 \\
\text { emergente } \times 1= & - \\
\text { em processo } \times 2= & - \\
\text { adquirido } \times 3= & - \\
\text { Total de pontos } & -\end{array}$ & \\
\hline
\end{tabular}

Figures 1F- Final FAPI translation into Portuguese (original in English: Stredler-Brown \& Johnson ${ }^{25}$ ) 


\begin{tabular}{|c|c|c|c|}
\hline $\begin{array}{l}\text { Categoria de } \\
\text { Desenvolvimento } \\
\text { Auditivo }\end{array}$ & Indicadores de Desempenho Auditivo & $\begin{array}{c}\text { Pontuação } \\
N=0-10 \%, \quad E=11-35 \% \\
P=36-79 \%, \quad A=80-100 \%\end{array}$ & $\begin{array}{l}\text { Observações } \\
\text { e Comentários }\end{array}$ \\
\hline 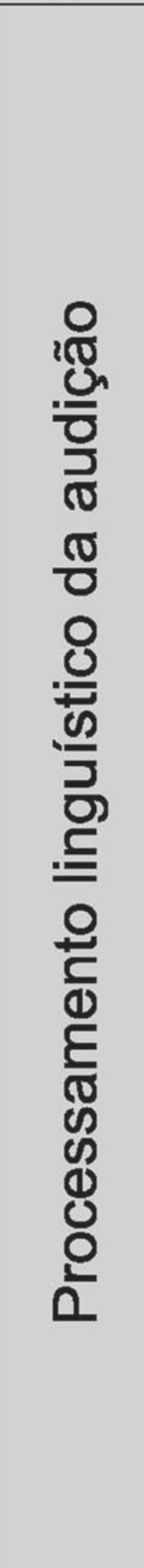 & 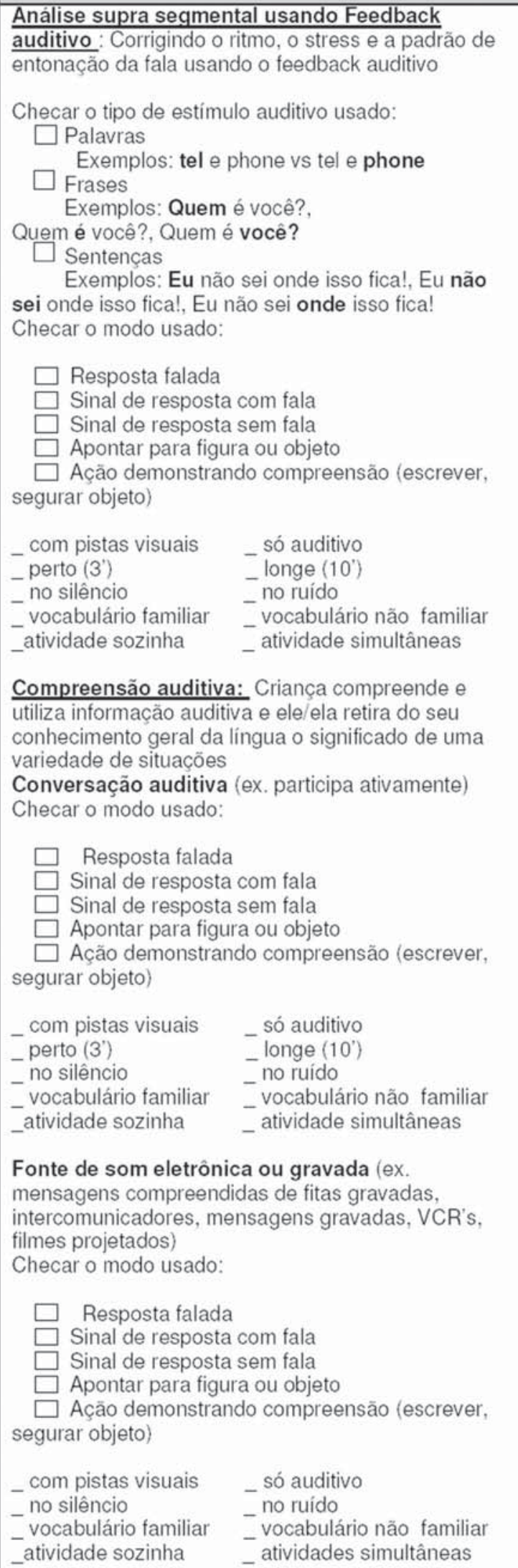 & $\begin{array}{ll}\text { não presente= } & 0 \\
\text { - emergente } \times 1= & - \\
\text { em processo } \times 2= & - \\
\text { adquirido } \times 3= & - \\
\text { Total de pontos } & - \\
& \\
& \\
& \\
\text { - não presente }= & 0 \\
\text { emergente } \times 1= & - \\
\text { em processo } \times 2= & - \\
\text { em adquirido } \times 3= & - \\
\text { Total de pontos } & -\end{array}$ & \\
\hline
\end{tabular}

Figures 1G- Final FAPI translation into Portuguese (original in English: Stredler-Brown \& Johnson ${ }^{25}$ ) 


\begin{tabular}{|c|c|c|c|c|c|}
\hline $\begin{array}{l}\text { Categoria de } \\
\text { Desenvolvimento } \\
\text { Auditivo }\end{array}$ & \multicolumn{2}{|c|}{ Indicadores de Desempenho Auditivo } & \multicolumn{2}{|c|}{ Pontuação } & $\begin{array}{c}\text { Observaçõe } \\
\text { s e } \\
\text { Comentários }\end{array}$ \\
\hline$\frac{10}{10}$ & $\begin{array}{l}\text { Conversa por telefone } \\
\text { telefônica) } \\
\text { Checar o modo usado: } \\
\square \text { Resposta falada } \\
\square \text { Sinal de resposta } \\
\square \text { Sinal de resposta } \\
\square \text { Apontar para figu } \\
\square \text { Ação demonstrar } \\
\text { segurar objeto) } \\
\text { _no silêncio } \\
\text { - vocabulário familiar } \\
\text { _atividade sozinha } \\
\text { Conteúdo acadêmico: } \\
\text { informaçöes em sala de } \\
\text { Checar o modo usado: } \\
\square \text { Resposta falada } \\
\square \text { Sinal de resposta } \\
\square \text { Sinal de resposta } \\
\square \text { Apontar para figu } \\
\square \text { Ação demonstrar } \\
\text { segurar objeto) } \\
\text { _com pistas visuais } \\
\text { - no silêncio } \\
\text { - vocabulário familiar } \\
\text {-atividade sozinha } \\
\text { Instruções (Escutar ao } \\
\text { memória e seqüencianc } \\
\text { Checar o modo usado: } \\
\square \text { Resposta falada } \\
\square \text { Sinal de resposta } \\
\square \text { Sinal de resposta } \\
\square \text { Apontar para figu } \\
\square \text { Ação demonstrar } \\
\text { segurar objeto) } \\
\text { _ com pistas visuais } \\
\text { - no silêncio } \\
\text { _ vocabulário familiar } \\
\text { _atividade sozinha }\end{array}$ & 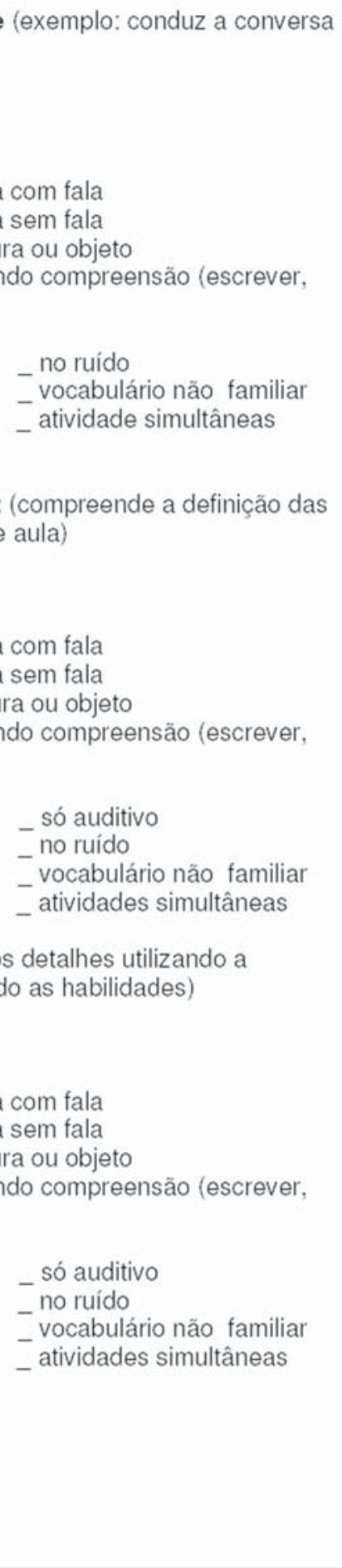 & $\begin{array}{l}\text { não presente= } \\
- \text { emergente } \times 1= \\
\text { - em processo } \times 2= \\
\text { adquirido } \times 3= \\
\text { Total de pontos } \\
\\
\\
\text { - não presente= } \\
\text { - emergente } \times 1= \\
\text { em processo } \times 2= \\
\text { adquirido } \times 3= \\
\text { Total de pontos } \\
\text { Pontuação na categ } \\
\text { /234 } \%\end{array}$ & $\begin{array}{l}0 \\
- \\
- \\
- \\
- \\
\text { goria: }\end{array}$ & \\
\hline
\end{tabular}

Figures 1H- Final FAPI translation into Portuguese (original in English: Stredler-Brown \& Johnson ${ }^{25}$ ) 
Indicadores de Performance Funcional Auditiva: Uma Abordagem Integrada do Desenvolvimento da Habilidade Auditiva Nome: FCR Idade: 7 a. 4 m. DN: 02/08/2001 Data: 04/12/2008 Examinador: KF $\quad$ usuário desde os 4 anos implante ZAASI $^{\text {AAs }}$

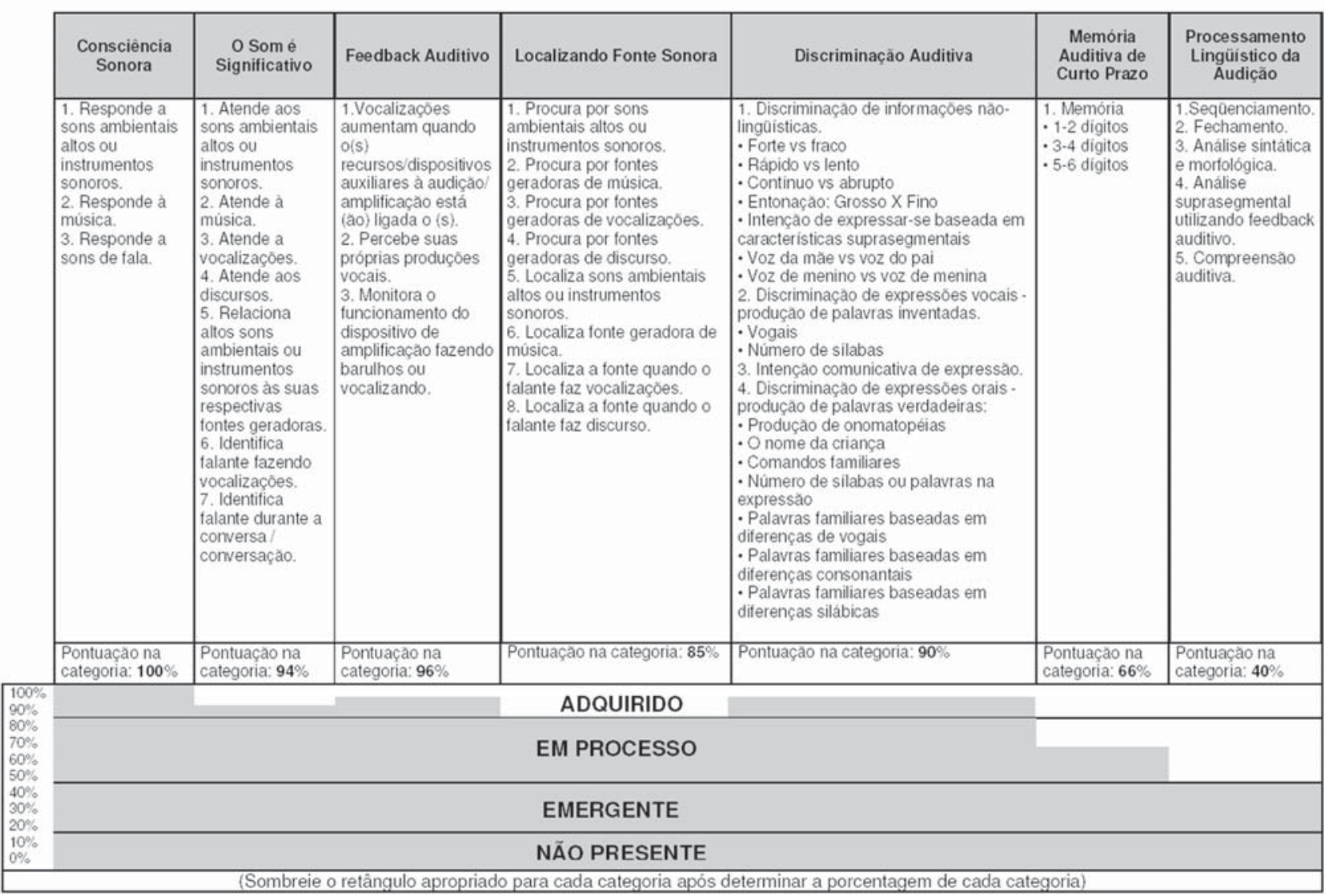

Figure 2- Evaluation results using the Brazilian FAPI (original in English: Stredler-Brown \& Johnson ${ }^{25}$ ) 